\title{
REDUKSI KOMPONEN TOKSIK DARI LIMBAH CAIR GARMEN MENGGUNAKAN BIO-ANORGANIK-SORBEN ARANG TULANG
}

\author{
Ni Gusti Ayu Made Dwi Adhi S.*, I Nengah Simpen, Anak Agung Bawa Putra \\ Jurusan Kimia Fakultas Matematika dan Ilmu Pengetahuan Alam, Universitas Udayana, Bukit Jimbaran, Bali- \\ Indonesia \\ *duadhi@yahoo.com
}

\begin{abstract}
ABSTRAK: Tujuan penelitian ini adalah mempelajari kemampuan adsorpsi arang tulang sapi teraktivasi $\mathrm{NaOH} \mathrm{0,4} \mathrm{M} \mathrm{untuk} \mathrm{menurunkan} \mathrm{(reduksi)} \mathrm{karakteristik} \mathrm{tingkat} \mathrm{kekeruhan,}$ $\mathrm{COD}$ (chemical oxygen demand), kandungan $\mathrm{Cr}$ dan $\mathrm{Pb}$ dari limbah garmen yang dibandingkan dengan tanpa aktivasi. Kemampuan adsorpsi arang tulang tanpa dan teraktivasi (bio-anorganik-sorben) terhadap karakteristik limbah tersebut dikaitkan dengan karakterisasi (keasaman permukaan, jumlah situs aktif, gugus fungsi dan luas permukaan spesifik) serta waktu dan volume interaksi optimum. Hasil yang diperoleh bahwa aktivasi arang tulang dengan larutan $\mathrm{NaOH}$ 0,4 M dapat meningkatkan karakteristiknya (keasaman permukaan, jumlah situs aktif, intensitas gugus fungsi O-H dan luas permukaan spesifik) dibandingkan dengan yang tanpa aktivasi. Aktivasi $\mathrm{NaOH}$ pada arang tulang dapat meningkatkan kemampuan adsorpsi dalam menurunkan tingkat kekeruhan, $\mathrm{COD}$, dan kandungan $\mathrm{Cr}$ dan $\mathrm{Pb}$ dari sampel limbah cair garmen dibandingkan dengan kemampuan arang tanpa aktivasi. Waktu interaksi optimum yang diperlukan dalam menurunkan karakteristik tingkat kekeruhan dan COD adalah 90 menit, dengan volume interaksi optimum $20 \mathrm{~mL}$.
\end{abstract}

Kata kunci: kekeruhan, COD, limbah cair garmen, arang tulang sapi

\begin{abstract}
The aim of this reseach was to study the adsorption ability of cow bone charcoal activated with $0.4 \mathrm{M} \mathrm{NaOH}$ to reduce the turbidity level, the chemical oxygen demand (COD), the $\mathrm{Pb}$ and $\mathrm{Cr}$ content of garment waste water and to compare with the nonactivated ones. The adsorption ability of both activated and non-activated bone charcoal (bioinorganic-sorbent) was related to their characteristics which are the surface acidity, the active sites, the fuction groups, the specific surface area, the volume and time optimum interaction as well. The result showed that activation can increase the surface acidity, the active sites, the $\mathrm{O}-\mathrm{H}$ fuction groups intensity and the specific surface area compared with non-activated ones. The activated charcoal significantly reduced the COD and the turbidity level, the $\mathrm{Pb}$ and $\mathrm{Cr}$ content of garment waste water comparing with the non-activated ones. Time contact optimum to reduce its characteristics is 90 minutes and volume interaction optimum is 20 $\mathrm{mL}$.
\end{abstract}

Keywords: turbidity, COD, waste water of garment, charcoal of bone

\section{PENDAHULUAN}

Industri garmen (pencelupan) skala kecil, umumnya belum dilengkapi dengan sistem pengolahan limbah sehingga diperlukan sistem pengolahan limbah secara sederhana, mudah dalam pengolahannya dan tidak memerlukan biaya yang terlalu besar. Kurangnya kesadaran dan minimnya informasi yang diperoleh pengusaha industri pencelupan (dyes), serta besarnya biaya pengolahan limbah, menyebabkan limbah tersebut tidak diolah secara maksimum, bahkan tidak sedikit yang membuangnya secara 
langsung ke lingkungan perairan secara langsung. Keadaan ini jika tidak segera ditanggulangi akan menyebabkan menurunnya kualitas lingkungan secara serius [1].

Limbah cair garmen (dyes) memiliki karakteristik dan komposisi fisiko-kimia. Material tersuspensi, warna dan bau merupakan karakteristik fisik, sementara $\mathrm{pH}, \mathrm{BOD}$, dan COD realtif tinggi, komposisi persenyawaan yang sulit terurai, bahan organik (serat-serat kain) dari bahan tekstil [2], dan logam berat yang sebagian besar mengandung $\mathrm{Pb}$ dan/atau $\mathrm{Cr}[3,4]$ merupakan karakteristik kimia. Bila berinteraksi dengan ion logam $\mathrm{Cr}$ dalam jangka waktu yang panjang dapat menyebabkan pembengkakan pada ginjal, menyebabkan kanker paru-paru [1], merusak ginjal, menyebabkan enzim tidak aktif dan reaksi alergi kulit [5]. Sementara, ion logam $\mathrm{Pb}$ dapat menyebabkan kerusakan pada otak dan kejang-kejang [6]. Mengingat dampak negatif yang ditimbulkan oleh limbah pencelupan terhadap makhluk hidup dan lingkungan, maka keberadaan limbah tersebut perlu mendapat perhatian secara serius, terutama proses pengolahannya untuk mereduksi (mengurangi) zat berbahaya (toksik). Pengolahan limbah dapat dilakukan dengan berbagai cara, salah satunya adalah melalui adsorpsi oleh mineral alami bioanorganik-sorben.

Akhir-akhir ini, adsorben jenis karbon aktif yang paling umum digunakan untuk mengadsorpsi kandungan limbah, akan tetapi karena tingginya harga dan tingkat seletivitas adsorben tersebut serta sulitnya diregenerasi (daur ulang), mendorong pentingnya untuk mencari material lain sebagai penggantinya [4]. Salah satu bahan yang menarik untuk digunakan sebagai adsorben alternatif adalah tulang sapi limbah ukiran yang telah diarangkan. Komposisi kimia tulang yang telah kering terdiri dari bahan organik dan anorganik dengan rasio 1:2. Bahan anorganik pada tulang sapi mengandung kalsium (32,6\%), fosfor
$(15,2 \%)$, dan sisanya terdiri dari natrium, kalium, magnesium, tembaga, kobal, seng, mangan, dan sulfur [7]. Penyusun tulang sapi sebagian besar adalah bio-anorganik hidroksiapatit $\quad\left[\mathrm{Ca}_{10}\left(\mathrm{PO}_{4}\right)_{6}(\mathrm{OH})_{2}\right]$. Hidroksiapatit dapat digunakan sebagai adsorben karena memiliki pori, resorpsi, inert, dan tahan aus [8,9]. Selain itu, hidroksiapatit dapat digunakan sebagai penukar ion yang mampu menurunkan kadar beberapa logam dalam larutan seperti ion $\mathrm{Cd}^{2+}, \mathrm{Hg}^{2+}, \mathrm{Zn}^{2+}$, dan $\mathrm{Pb}^{2+}$ [8]. Keunggulan adsorben berbahan baku tulang dari limbah kerajinan dibandingkan adsorben lain adalah mudah didapat sehingga secara ekonomi harganya sangat murah, cukup melimpah jumlahnya karena dapat diperbaharui (renewable), tidak toksik (tergolong biomaterial), serta ramah lingkungan (biodegradable) [8,9].

Selama ini arang tulang sapi banyak dimanfaatkan dalam industri gula pada proses pemucatan warna untuk menghasilkan gula putih [10]. Menurut penelitian Permana (2010), arang tulang sapi teraktivasi $\mathrm{NaOH} \quad 0,4 \mathrm{M}$ memiliki kapasitas adsorpsi yang paling besar terhadap larutan standar (model) logam Cr(III) yaitu 485,8167 mg/g dibandingkan modifikasi lainnya $(79,1387 \mathrm{mg} / \mathrm{g})$ [11]. Oleh karena itu, pada penelitian ini aktivasi arang tulang menggunakan larutan $\mathrm{NaOH} 0,4 \mathrm{M}$.

Berdasarkan uraian tersebut di atas, dimungkinkan arang tulang berbahan baku limbah kerajinan dapat pula dimanfaatkan sebagai bio-anorganik-sorben terhadap limbah cair industri garmen. Oleh karena itu, dipelajari kemampuan adsorpsi arang tulang teraktivasi $\mathrm{NaOH} 0,4 \mathrm{M}$ terhadap kemampuan reduksi tingkat kekeruhan, COD (chemical oxygen demand), kandungan $\mathrm{Cr}$ dan $\mathrm{Pb}$ dari limbah cair garmen dibandingkan arang tulang tanpa aktivasi.

\section{PERCOBAAN}

\subsection{Bahan dan Peralatan}


Bahan-bahan yang digunakan adalah tulang sapi yang diperoleh dari limbah kerajinan ukiran di Desa Manukaya Anyer, Gianyar; limbah cair garmen dari industri garmen di Denpasar, air bebas ion (deionized water); dan aquades. Sementara, bahan kimia untuk preparasi, aktivasi dan adsorpsi meliputi: $\mathrm{HCl}$, $\mathrm{NaOH}, \mathrm{K}_{2} \mathrm{Cr}_{2} \mathrm{O}_{7}, \mathrm{~Pb}\left(\mathrm{NO}_{3}\right)_{2}$, biru metilen (methylene blue) dan indikator phenolphtalein (pp). Alat yang digunakan dalam penelitian ini adalah peralatan gelas, oven, tanur, desikator, pengaduk magnet, neraca analitik, batang pengaduk, kertas saring, ayakan ukuran $500 \mu \mathrm{m}$ dan $250 \mu \mathrm{m}$, spektrofotometer UV-vis, fourier transform infrared (FTIR), turbidimeter, dan atomic absorption spectrophotometer (AAS).

\subsection{Metode}

\section{Penyiapan sampel}

Tulang yang diperoleh dari hasil buangan pengrajin ukiran tulang dihancurkan dan digerus, kemudian diayak dengan ayakan lolos $500 \mu \mathrm{m}$ dan tertahan $250 \mu \mathrm{m}$ (serbuk dengan ukuran antara 250$500 \mu \mathrm{m})$. Serbuk tulang sapi tersebut dicuci dengan aquades, kemudian dikeringkan dalam oven pada suhu 105$110^{\circ} \mathrm{C}$ sampai berat konstan. Selanjutmya, serbuk tulang tersebut diarangkan dalam tanur pada suhu $300^{\circ} \mathrm{C}$ selama 1 jam, bila menggumpal dilakukan penggerusan. Setelah itu, arang tulang diberi kode $\mathrm{N}_{\mathrm{o}}$ dan disimpan dalam desikator untuk eksperimen lebih lanjut.

\section{Aktivasi arang tulang dengan $\mathrm{NaOH} 0,4$ M}

Enam puluh (60) gram serbuk arang tulang dimasukkan ke dalam gelas beaker, lalu ditambahkan $900 \mathrm{~mL}$ larutan $\mathrm{NaOH}$ 0,4 M sambil diaduk dengan pengaduk magnet selama 2,5 jam. Setelah itu, campuran disaring dan residu yang didapat dicuci dengan aquades (sampai terbebas dari ion $\mathrm{OH}^{-}$atau tes negatif terhadap pp). Selanjutnya, dikeringkan dalam oven pada suhu $110-120^{\circ} \mathrm{C}$ sampai berat konstan (bila menggumpal dilakukan penggerusan) dan diberi kode $\mathrm{N}_{\mathrm{A}}$ kemudian disimpan dalam desikator untuk eksperimen berikutnya.

\section{Karakterisasi bio-anorganik-sorben}

Produk antara bio-anorganik-sorben $\mathrm{N}_{\mathrm{o}}$ dan $\mathrm{N}_{\mathrm{A}}$ dikarakterisasi keasaman permukaan dan jumlah situs aktif secara titrasi asam basa, gugus fungsi dianalisis secara spektroskopi FTIR dan luas permukaan spesifik menggunakan metode methylene blue.

\section{Analisis awal limbah cair garmen}

Limbah cair garmen dianalisis karakteristik tingkat kekeruhan secara turbidimetri, COD secara reaksi kimia (refluksasi dan titrasi), dan kandungan $\mathrm{Cr}$ dan $\mathrm{Pb}$ secara spektrometri serapan atom (AAS).

Penentuan kemampuan adsorpsi bioanorganik-sorben terhadap beberapa karakteristik dan komposisi limbah cair garmen:

\section{a. Penentuan waktu interaksi optimum}

Disediakan 6 buah erlenmeyer 100 $\mathrm{mL}$, erlenmeyer diisi dengan 0,3 gram arang tulang $\mathrm{N}_{\mathrm{A}}$. Pada erlenmeyer tersebut ditambahkan 20,0 mL sampel limbah cair industri pencelupan, kemudian diaduk dengan pengaduk magnet selama waktu kontak bervariasi, yaitu 15, 30, 60, 90, 120, dan 150 menit [11]. Larutan hasil pengadukan disaring dan dilakukan analisis yang sama pada analisis awal limbah cair garmen. Cara yang sama dilakukan juga untuk adsorben $\mathrm{N}_{\mathrm{o}}$ (sebagai pembanding).

\section{b. Penentuan volume interaksi optimum}

Disediakan 5 buah erlenmeyer 100 $\mathrm{mL}$, masing-masing erlenmeyer diisi dengan 0,3 gram arang tulang $\mathrm{N}_{\mathrm{A}}$. Pada erlenmeyer tersebut ditambahkan sampel limbah cair industri pencelupan dengan volume yang bervariasi, yaitu 5, 10, 20, 30, dan $45 \mathrm{~mL}$, kemudian diaduk dengan 
Tabel 1. Karakteristik Arang Tulang Sapi Sebagai Adsorben Tanpa $\left(\mathrm{N}_{\mathrm{o}}\right)$ dan Dengan Aktivasi $\left(\mathrm{N}_{\mathrm{A}}\right) \mathrm{NaOH} 0,4 \mathrm{M}$.

\begin{tabular}{cccc}
\hline Adsorben & $\begin{array}{c}\text { Keasaman permukaan } \\
(\mathrm{mmol} / \mathrm{gram})\end{array}$ & $\begin{array}{c}\text { Jumlah situs aktif } \\
(\mathrm{x} \mathrm{10} 20\end{array}$ & $\begin{array}{c}\text { Luas permukaan } \\
\left(\mathrm{m}^{2} / \mathrm{g}\right)\end{array}$ \\
\hline $\mathrm{N}_{\mathrm{o}}$ & 0,6044 & 3,6397 & 10,1895 \\
$\mathrm{~N}_{\mathrm{A}}$ & 0,7280 & 4,3840 & 20,0803 \\
\hline
\end{tabular}

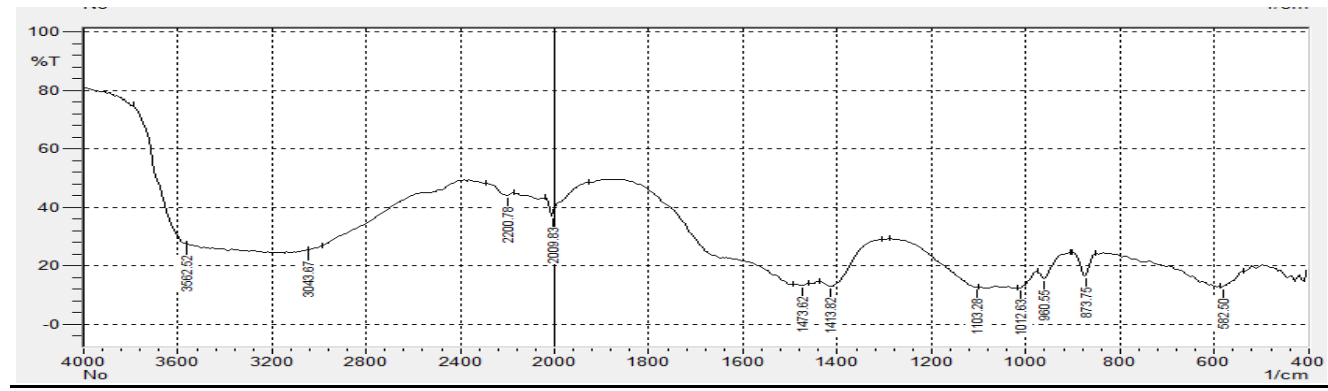

(a)

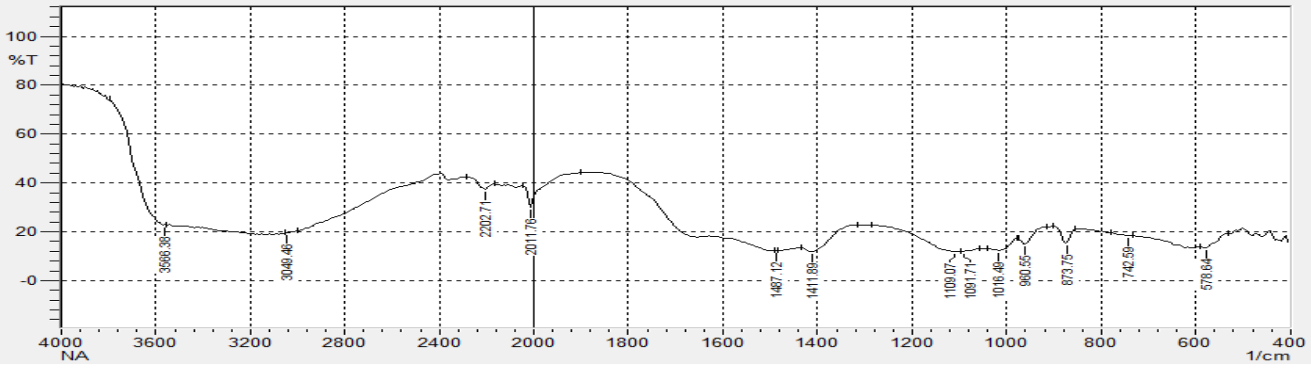

(b)

Gambar 1. Spektra FTIR (a) arang tulang sapi tanpa aktivasi $\left(\mathrm{N}_{\mathrm{o}}\right)$ dan (b) teraktivasi $\mathrm{NaOH}$ $0,4 \mathrm{M}\left(\mathrm{N}_{\mathrm{A}}\right)$

pengaduk magnet selama waktu interaksi optimum yang didapat dari proses penentuan waktu interaksi optimum. Setelah itu dilakukan pengadukan dan disaring, kemudian dilakukan analisis yang sama pada analisis awal limbah cair garmen. Cara yang sama dilakukan juga untuk adsorben $\mathrm{N}_{\mathrm{o}}$ (sebagai pembanding).

\section{HASIL DAN PEMBAHASAN}

Berdasarkan Tabel 1, arang tulang teraktivasi menggunakan larutan $\mathrm{NaOH}$ 0,4 $\mathrm{M}\left(\mathrm{N}_{\mathrm{A}}\right)$ dapat meningkatkan keasaman permukaan dan jumlah situs aktif dibandingkan tanpa aktivasi (adsorben kontrol). Artinya, aktivasi menggunakan larutan $\mathrm{NaOH} \quad 0,4 \quad \mathrm{M}$ telah dapat melarutkan pengotor-pengotor yang menyumbat pori-pori adsorben kontrol $\left(\mathrm{N}_{\mathrm{o}}\right)$, sehingga pori menjadi lebih terbuka. Sementara, luas permukaan spesifik adsorben $\mathrm{N}_{\mathrm{A}}$ lebih besar dibandingkan adsorben kontrol, yaitu $20,0803 \mathrm{~m}^{2} / \mathrm{g}$. Hal ini kemungkinan disebabkan bahwa adanya proses pengarangan dan aktivasi $\mathrm{NaOH}$ 0,4 M mengakibatkan lebih banyak pengotor yang larut sehingga permukaan pori menjadi relatif lebih terbuka.

Berdasarkan Gambar 1 dan terangkum dalam Tabel 2, gugus $\mathrm{O}-\mathrm{H}$ muncul dengan intensitas lebih kuat dan bilangan gelombang meningkat pada adsorben $\mathrm{N}_{\mathrm{A}}$ dibandingkan $\mathrm{N}_{\mathrm{o}}$. Gugus $\mathrm{O}-\mathrm{H}$ bending pada bilangan gelombang di sekitar 742,59 $\mathrm{cm}^{-1}$ tidak muncul pada adsorben $\mathrm{N}_{\mathrm{o}}$. Artinya, situs asam Bronsted cenderung bertambah banyak $[9,12]$. Hal ini sejalan dengan hasil keasaman permukaan dan 
Tabel 2. Bilangan Gelombang Spektra FTIR Adsorben

\begin{tabular}{ccc}
\hline \multirow{2}{*}{ Gugus fungsi } & \multicolumn{2}{c}{$\begin{array}{c}\text { Bilangan gelombang }\left(\mathrm{cm}^{-1}\right), \\
\text { dari adsorben }\end{array}$} \\
& $\mathbf{N}_{\mathbf{0}}$ & $\mathbf{N}_{\mathbf{A}}$ \\
\hline $\mathrm{O}-\mathrm{H}$ & - & 742,59 \\
$\mathrm{Ca}-\mathrm{O}$ & 14562,52 & 3566,38 \\
& $1473,82 \mathrm{dan}$ & $1411,69 \mathrm{dan}$ \\
$\mathrm{PO}_{4}{ }^{3-}$ & $582,60 \mathrm{dan}$ & 1487,12 \\
& 960,55 & $976,64 \mathrm{dan}$ \\
$\mathrm{CO}_{3}{ }^{2-}$ & 873,75 & 873,55 \\
& & \\
\hline
\end{tabular}

Tabel 3. Nilai Awal Kekeruhan, COD, Kandungan $\mathrm{Cr}$ dan $\mathrm{Pb}$ Limbah Garmen

\begin{tabular}{cc}
\hline Parameter & Nilai Awal \\
\hline Kekeruhan & 83,00 \\
$(\mathrm{NTU})$ & \\
$\mathrm{COD}(\mathrm{ppm})$ & 598,67 \\
$\mathrm{Cr}(\mathrm{ppm})$ & 0,7143 \\
$\mathrm{~Pb}(\mathrm{ppm})$ & 1,9461 \\
\hline
\end{tabular}

jumlah situs aktif (Tabel 1). Sementara, gugus fungsi $\mathrm{Ca}-\mathrm{O} ; \mathrm{PO}_{4}{ }^{3-}$ dan $\mathrm{CO}_{3}{ }^{2-}$ muncul di kedua adsorben, dengan sedikit mengalami pergeseran bilangan gelombang.

Berdasarkan peraturan Permenkes RI tahun 1990 dan tahun 1997, semua nilai karakteristik yang diukur telah melewati ambang batas yang diperbolehkan. Nilai karakteristik tersebut (Tabel 3), digunakan sebagai kontrol (pembanding) awal untuk selanjutnya diadsorpsi oleh adsorben, sehingga akan diketahui berapa penurunan dari nilai karakteristik limbah tersebut.

Berdasarkan Tabel 4, waktu interaksi 15 sampai 90 menit terjadi penurunan tingkat kekeruhan, namun pada waktu interaksi 120 sampai 150 menit terjadi penurunan kemampuan adsorben. Hal ini diduga karena ikatan yang terjadi antara adsorben dan adsorbat sangat lemah, sehingga ikatan yang terjadi mudah putus. Diduga, ikatan yang terbentuk adalah ikatan molekular van der Waals. Adsorben $\mathrm{N}_{\mathrm{A}}$ dengan waktu interaksi 90 menit memiliki kemampuan adsorpsi terbaik. Menurut Permenkes RI No. 173/MenKes/ Per/VIII/1977, batas maksimum nilai kekeruhan yang diperbolehkan pada air limbah atau air buangan adalah 25 NTU. Berdasarkan hasil pengukuran, penurunan kekeruhan dari adsorpsi oleh kedua jenis adsorben, maka adsorben tersebut efektif.

Penurunan nilai COD sampel limbah disebabkan adanya adsorpsi zat-zat kimia oleh adsorben, sehingga kandungan zat-zat kimia tersebut menurun. Situs aktif dan luas permukaan spesifik dari adsorben mempengaruhi kemampuan adsorpsi adsorben terhadap zat-zat kimia yang terdapat dalam sampel limbah. Semakin banyak situs aktif dan luas permukaan spesifik, maka kemampuan adsorben untuk menyerap adsorbat akan semakin besar pula. Penurunan nilai COD optimum terjadi pada adsorben $\mathrm{N}_{\mathrm{A}}$ dengan waktu interaksi 90 menit, dimana nilai COD sampel limbah awal 598,07 ppm menurun menjadi $65,93 \mathrm{ppm}$. Sementara pada $\mathrm{N}_{\mathrm{o}}$, penurunan nilai COD optimum pada waktu interaksi 90 menit, namun tingkat penurunan COD lebih kecil, yaitu dari 598,67 ppm menjadi 217,58 ppm. Hal ini disebabkan $\mathrm{N}_{\mathrm{o}}$ mempunyai situs aktif dan luas permukaan spesifik yang lebih sedikit

Tabel 4. Nilai Kekeruhan dan COD Sampel Limbah Setelah Adsorpsi dalam Variasi Waktu Kontak

\begin{tabular}{ccccc}
\hline \multirow{2}{*}{$\begin{array}{c}\text { Waktu interaksi } \\
\text { (menit) }\end{array}$} & \multicolumn{2}{c}{$\begin{array}{c}\text { Kekeruhan dan COD setelah teradsorpsi } \\
\text { adsorben } \mathrm{N}_{\mathrm{o}}\end{array}$} & $\begin{array}{c}\text { Kekeruhan dan COD setelah teradsorpsi } \\
\text { adsorben } \mathrm{N}_{\mathrm{A}}\end{array}$ \\
\cline { 2 - 5 } & Kekeruhan (NTU) & COD $(\mathrm{ppm})$ & Kekeruhan (NTU) & COD (ppm) \\
\hline 15 & 47,67 & 503,73 & 22,67 & 444,39 \\
30 & 37,00 & 437,80 & 24,67 & 429,89 \\
60 & 27,33 & 398,24 & 20,33 & 320,44 \\
90 & 19,33 & 217,58 & 11,33 & 65,93 \\
120 & 26,33 & 361,31 & 11,67 & 259,78 \\
150 & 51,67 & 440,43 & 30,00 & 363,95 \\
\hline
\end{tabular}


Tabel 5. Jumlah $\mathrm{Cr}$ dan Pb yang Teradsorpsi (mg/g) dalam Variasi Waktu Kontak

\begin{tabular}{|c|c|c|c|c|}
\hline \multirow{2}{*}{$\begin{array}{l}\text { Waktu interaksi } \\
\text { (menit) }\end{array}$} & \multicolumn{2}{|c|}{$\begin{array}{c}\text { Jumlah } \mathrm{Cr} \text { dan } \mathrm{Pb} \text { teradsorpsi } \\
\text { adsorben } \mathrm{N}_{\mathrm{o}}\end{array}$} & \multicolumn{2}{|c|}{$\begin{array}{l}\text { Jumlah } \mathrm{Cr} \text { dan } \mathrm{Pb} \text { teradsorpsi adsorben } \\
\qquad \mathrm{N}_{\mathrm{A}}\end{array}$} \\
\hline & $\begin{array}{c}\mathrm{Cr} \\
(\mathrm{mg} / \mathrm{g})\end{array}$ & $\begin{array}{c}\mathrm{Pb} \\
(\mathrm{mg} / \mathrm{g})\end{array}$ & $\begin{array}{c}\mathrm{Cr} \\
(\mathrm{mg} / \mathrm{g})\end{array}$ & $\begin{array}{c}\mathrm{Pb} \\
(\mathrm{mg} / \mathrm{g})\end{array}$ \\
\hline 15 & 0,0361 & 0,0040 & 0,0394 & 0,0160 \\
\hline 30 & 0,0394 & 0,0120 & 0,0427 & 0,0439 \\
\hline 60 & 0,0394 & 0,0120 & 0,0427 & 0,0640 \\
\hline 90 & 0,0427 & 0,0958 & 0,0460 & 0,0998 \\
\hline 120 & 0,0427 & 0,0538 & 0,0394 & 0,0878 \\
\hline 150 & 0,0427 & 0,0439 & 0,0394 & 0,0758 \\
\hline
\end{tabular}

Tabel 6. Nilai Kekeruhan dan COD Sampel Limbah Setelah Adsorpsi dalam Variasi Volume Kontak pada Waktu Kontak 90 Menit

\begin{tabular}{ccccc}
\hline \multirow{2}{*}{$\begin{array}{c}\text { Volume } \\
\text { interaksi } \\
(\mathrm{mL})\end{array}$} & \multicolumn{2}{c}{$\begin{array}{c}\text { Kekeruhan dan COD setelah } \\
\text { teradsorpsi adsorben } \mathrm{N}_{\mathrm{o}}\end{array}$} & $\begin{array}{c}\text { Kekeruhan dan COD setelah teradsorpsi } \\
\text { adsorben } \mathrm{N}_{\mathrm{A}}\end{array}$ \\
\cline { 2 - 5 } & Kekeruhan $(\mathrm{NTU})$ & $\begin{array}{c}\mathrm{COD} \\
(\mathrm{ppm})\end{array}$ & $\begin{array}{c}\text { Kekeruhan } \\
(\text { NTU) }\end{array}$ & $\begin{array}{c}\mathrm{COD} \\
(\mathrm{ppm})\end{array}$ \\
\hline 5 & 66,00 & 370,55 & 19,67 & 200,44 \\
10 & 45,00 & 338,90 & 18,00 & 158,24 \\
20 & 38,67 & 214,94 & 11,33 & 75,16 \\
30 & 42,33 & 238,68 & 17,33 & 126,59 \\
45 & 59,00 & 272,96 & 21,67 & 183,29 \\
\hline
\end{tabular}

dibandingkan $\mathrm{N}_{\mathrm{A}}$ (Tabel 1, 2, dan 3).

Setelah adsorpsi, terjadi penurunan secara signifikan terhadap kandungan ion $\mathrm{Cr}$ dan $\mathrm{Pb}$. Ini berarti, adsorpsi oleh adsorben $\mathrm{N}_{\mathrm{o}}$ dapat menurunkan konsentrasi ion $\mathrm{Cr}$ dan $\mathrm{Pb}$ dalam sampel limbah berturut-turut 0,0427 dan 0,0958 $\mathrm{mg} / \mathrm{g}$ pada waktu interaksi 90 menit. Sementara, adsorben $\mathrm{N}_{\mathrm{A}}$ juga dapat menurunkan konsentrasi ion $\mathrm{Cr}$ dan $\mathrm{Pb}$ berturut-turut 0,0460 dan $0,0998 \mathrm{mg} / \mathrm{g}$ dengan waktu interaksi optimum 90 menit dengan jumlah lebih tinggi dibandingkan tanpa aktivasi $\left(\mathrm{N}_{\mathrm{o}}\right)$.

Berdasarkan Tabel 6, diperoleh bahwa terjadi penurunan nilai kekeruhan dari sampel limbah awal 83 NTU hingga menjadi 11,33 NTU oleh adsorben $\mathrm{N}_{\mathrm{A}}$ dan 38,67 NTU oleh adsorben $\mathrm{N}_{\mathrm{o}}$ pada volume interaksi $20 \mathrm{~mL}$ (Tabel 6). Adsorben $\mathrm{N}_{\mathrm{A}}$ dapat meningkatkan kemampuan adsorpsi sehingga tingkat kekeruhan sampel limbah dapat menurun setelah di interaksikan pada adsorben tersebut. Aktivasi arang tulang sapi menggunakan $\mathrm{NaOH}$ dapat melarutkan pengotor yang menutupi pori- pori adsorben tersebut, sehingga pori-pori lebih terbuka. Akibatnya, luas permukaan spesifik adsorben menjadi meningkat dan berdampak pada kemampuan adsorpsi juga menjadi maksimum. Sementara, terjadi menurunan nilai COD yang signifikan yaitu hingga $214,94 \mathrm{mg} / \mathrm{L}$ oleh adsorben $\mathrm{N}_{\mathrm{o}}$ dan $75,16 \mathrm{mg} / \mathrm{L}$ oleh adsorben $\mathrm{N}_{\mathrm{A}}$, dibandingkan nilai COD sampel limbah awal adalah 594,04 mg/L pada volume interaksi optimum adalah $20 \mathrm{~mL}$.

Kapasitas adsorpsi dari adsorben $\mathrm{N}_{\mathrm{o}}$ dan $\mathrm{N}_{\mathrm{A}}$ ditentukan dari jumlah ion $\mathrm{Cr}$ dan $\mathrm{Pb}$ yang teradsorpsi tiap gram adsorben, dimana terjadi interkasi ion-ion logam oleh situs aktif yang terdapat pada adsorben, Akibatnya, terjadi penurunan kandungan ion $\mathrm{Cr}$ dan $\mathrm{Pb}$ dalam sampel limbah. Aktivasi arang tulang sapi oleh $\mathrm{NaOH}$ dapat meningkatkan kemampuan adsorpsi arang tulang tersebut terhadap ion $\mathrm{Cr}$ dan $\mathrm{Pb}$. Proses aktivasi dapat meningkatkan keasaman permukaan arang tulang sapi, sehingga situs aktif baru yang terbentuk akan lebih maksimum. Adsorben 
Tabel 7. Jumlah $\mathrm{Cr}$ dan $\mathrm{Pb}$ yang Teradsorpsi (mg/g) dalam Variasi Volume Kontak pada Waktu Kontak 90 Menit

\begin{tabular}{ccccc}
\hline $\begin{array}{c}\text { Volume } \\
\text { interaksi } \\
(\mathbf{m L})\end{array}$ & \multicolumn{2}{c}{$\begin{array}{c}\text { Jumlah Cr dan Pb teradsorpsi } \\
\text { adsorben } \mathbf{N}_{\mathbf{o}}\end{array}$} & \multicolumn{2}{c}{$\begin{array}{c}\text { Jumlah Cr dan Pb teradsorpsi } \\
\text { adsorben } \mathbf{N}_{\mathbf{A}}\end{array}$} \\
\cline { 2 - 5 } & $\begin{array}{c}\mathrm{Cr} \\
(\mathrm{mg} / \mathrm{g})\end{array}$ & $\begin{array}{c}\mathrm{Pb} \\
(\mathrm{mg} / \mathrm{g})\end{array}$ & $\begin{array}{c}\mathrm{Cr} \\
(\mathrm{mg} / \mathrm{g})\end{array}$ & $\begin{array}{c}\mathrm{Pb} \\
(\mathrm{mg} / \mathrm{g})\end{array}$ \\
\hline 5 & 0,0057 & 0,0170 & 0,0066 & 0,0240 \\
10 & 0,0099 & 0,0439 & 0,0181 & 0,0499 \\
20 & 0,0394 & 0,0958 & 0,0460 & 0,1000 \\
30 & 0,0246 & 0,1138 & 0,0296 & 0,1257 \\
45 & 0,0148 & 0,1137 & 0,0369 & 0,1527 \\
\hline
\end{tabular}

teraktivasi $\left(\mathrm{N}_{\mathrm{A}}\right)$ dapat meningkatkan kapasitas adsorpsinya, optimum pada volume limbah $20 \mathrm{~mL}$. Berdasarkan Tabel 7, diperoleh bahwa kapasitas adsorpsi terhadap ion $\mathrm{Cr}$ lebih rendah dibandingkan terhadap ion $\mathrm{Pb}$. Hal ini diduga disebabkan bahwa ion $\mathrm{Cr}$ dalam air cenderung dalam bentuk anion $\mathrm{Cr}_{2} \mathrm{O}_{7}{ }^{2-}$ atau $\mathrm{Cr}(\mathrm{VI})$ dengan ukuran molekul terhidrasi lebih besar dibandingkan molekul $\mathrm{Pb}$ terhidrasi, sehingga relatif kurang leluasa bisa masuk ke dalam pori, akibatnya lebih sedikit dapat terikat pada situs adsorben dibandingkan $\mathrm{Pb}$, yang cenderung membentuk ion $\mathrm{Pb}(\mathrm{II})$. Fenomena ini didukung oleh penelitian Amri et al., (2004) bahwa jumlah Cr(III) yang teradsorpsi lebih rendah dibandingkan $\mathrm{Cd}(\mathrm{II})$ walaupun muatan $\mathrm{Cr}$ lebih tinggi dibandingkan Cd [13]. Hal ini disebabkan oleh reaksi spesifik yang terjadi antara adsorbat dengan permukan adsorben dan perbedaan sifat antara pori-pori serta dipengaruhi pula oleh kekuatan medan elektrostatis.

\section{KESIMPULAN}

Dari hasil yang telah dicapai, dapat disimpulkan bahwa aktivasi arang tulang dengan larutan $\mathrm{NaOH} 0,4 \mathrm{M}\left(\mathrm{N}_{\mathrm{A}}\right)$ dapat meningkatkan karakteristiknya (keasaman permukaan, jumlah situs aktif, intensitas gugus fungsi $\mathrm{O}-\mathrm{H}$ dan luas permukaan spesifik) dibandingkan tanpa aktivasi $\left(\mathrm{N}_{\mathrm{o}}\right)$. Aktivasi $\mathrm{NaOH}$ pada arang tulang sapi dapat meningkatkan kemampuan adsorpsinya dalam menurunkan karakteristik tingkat kekeruhan, COD, kandungan $\mathrm{Cr}$ dan $\mathrm{Pb}$ dari sampel limbah dibandingkan tanpa aktivasi. Waktu interaksi optimum yang diperlukan dalam menurunkan karakteristik tingkat kekeruhan, COD, kandungan $\mathrm{Cr}$ dan $\mathrm{Pb}$ adalah 90 menit, dengan volume interaksi optimum $20 \mathrm{~mL}$.

\section{UCAPAN TERIMAKASIH}

Pada kesempatan ini, diucapkan terimakasih kepada Lembaga Penelitian dan Pengabdian kepada Masyarakat (LPPM) Universitas Udayana melalui Fakultas MIPA atas penelitian HUPS tahun 2015. Serta, disampaikan pula kepada teman sejawat di Jurusan Kimia Fakultas MIPA Universitas Udayana atas kontribusi pemikirannya.

\section{DAFTAR PUSTAKA}

[1] Oladoja, N.A., Aboluwaye, C.O. and Oladimeji, Y.B., 2008. Kinetiks and Isoterm Studies on Methyelene Blue Adsorption onto Ground Palm Kernel Coat. Turkish J. Eng. Sci. 32: 303-312.

[2] Anonim, 1984. Proses Pengolahan Limbah Industri Tekstil dalam Rangka Menanggulangi Pencemaran Pencemaran Lingkungan (pewarna celup). Laporan Penelitian. Balitbang Industri Semarang. Departemen Perindustrian Semarang. Semarang.

[3] Reichert, J. and Binner, J.G.P., 1996. An Evaluation of Hydroxyapatitebased Filters for Removel of Heavy Metal Ions from Aqueous Solutions. Journal of Materials Science. 31: 1231-1241. 
[4] Fuqiang, L., Jinlong, C., Aimin, L., Zhenghao, F, Junjie, G. and Quanxing, Z., 2004. Equilibrium Adsorption of Single Component and Binary Mixtures of Aromatic Compound onto a Polyfunctional Hypercrosslinked Poltmeric Adsorbent. Journal of Adsorption Science and Technology. 22 (1): 13-24.

[5] Dermatas, D. and Meng, X., 2004. Removal of As, Cr, and $\mathrm{Cd}$ by Adsorptive Filtration. Global Nest. The Int. J. 5 (1): 73-80.

[6] Anonim., 2005. Dampak Pencemaran $\mathrm{Pb}$ Terhadap Kesehatan Masyaraka. www.pdpersi.co.id. (Diakses 9 Januari 2010).

[7] Elkayar, A., Elshazly, Y. and Assaad, M., 2009. Properties of Hydroxyapatite from Bovine Teeth. Bone and Tissue Regeneration Insights. 2: 31-36.

[8] Wahl, D.A. and Czernuszka, J.T. 2006. Collagen-Hydroxyapatite Composites For Hard Tissue Repair. European Cell and Materials. Vol. 11. 43-56.

[9] Barakat, N.A.M., Khil, M.S., Omran, A.M., Sheikh, F.H. and Kim, H.Y., 2009. Extraction of Pure Natural
Hydroxyapatite From The Bovine Bones Bio Waste by Three Different Methods. Journal of Materials Processing Technology. 209. 34083415.

[10] Anonim. 1997. www.cuneyttes.com/ biomim. htm. (Diakses 9 Januari 2010).

[11] Permana, C.R.I., 2010. Adsorpsidesorpsi Serbuk dan Arang Tulang Sapi

Teraktivasi $\mathrm{NaOH}$ 0,4 $\mathrm{M}$ dan Tersalut $\mathrm{Fe}_{2} \mathrm{O}_{3}$ Terhadap Logam $\mathrm{Cr}$ (III). Skripsi. Universitas Udayana. Denpasar.

[12] Kusrini E. and Sontang M., 2012. Characterization of X-ray difraction and electron spin resonance: effects of sintering time and temperature on bovine hydroxyapatite. Rad Phis \& Chem 81: 118-125.

[13] Amri, A., Supranto, dan Fahrurozi, M., 2004. Kesetimbangan Adsorpsi Opsional Campuran Biner Cd(II) dan Cr(III) dengan Zeolit Alam Terimpregnasi 2merkaptobenzotiazol. Jurnal Natur Indonesia. 6(2): 111-117. 